\title{
Analysis of Pulsatile and Surge-like Luteinizing Hormone Secretion with Frequent Blood Sampling in Female Mice
}

\author{
Shiori MINABE ${ }^{1)}$, Yoshihisa UENOYAMA ${ }^{1)}$, Hiroko TSUKAMURA ${ }^{1)}$ and Kei-ichiro MAEDA ${ }^{1)}$ \\ ${ }^{1)}$ Graduate School of Bioagricultural Sciences, Nagoya University, Nagoya 464-8601, Japan
}

\begin{abstract}
Mice have become more important as genetically-modified model animals for analysis of physiological functions. The establishment of a frequent blood sampling system in conscious mice would provide a powerful tool for a better and more detailed understanding of the physiological status of circulating hormonal changes, such as pulse or surge modes of luteinizing hormone (LH) secretion. Frequent blood sampling, however, is considered problematic in mice because of the limited blood volume for their small body size. The present study, therefore, aims to establish a blood sampling protocol to determine the pulse and surge modes of LH secretion using intra-atrial cannulation and frequent blood sampling in free-moving conscious mice. Ovariectomized mice were bled every $3 \mathrm{~min}$ for $1.5 \mathrm{~h}$ to detect LH pulses. Blood glucose levels, an indicator of stress, were kept constant throughout the 1.5-h sampling period, suggesting that sampling can be performed under stress-free conditions. Obvious LH pulses were observed in $a d$ lib-fed ovariectomized mice, whereas they were significantly suppressed after a 24-h fast. This indicates that the present sampling protocol is suitable for detecting physiological changes in pulsatile LH secretion. In addition, 1-h-interval blood collections in proestrous mice between 1300 and $2200 \mathrm{~h}$ revealed that individual preovulatory LH surges occur in the evening of proestrous days. Thus, the present study has developed a blood sampling protocol to detect individual profiles of pulse and surge modes of LH secretion in mice.
\end{abstract}

Key words: Cannulation, Gonadotropin, Luteinizing hormone (LH), Pulse

(J. Reprod. Dev. 57: 660-664, 2011)

$\mathbf{T}$ he analysis of circulating luteinizing hormone (LH) profiles via frequent blood sampling has provided a useful tool for assessing the activity of the hypothalamo-pituitary-gonadal axis in various mammalian species, such as rats [1], guinea pigs [2], pigs [3], sheep [4], goats [5], cows [6], rhesus monkeys [7] and horses [8]. There are two distinct modes of LH secretion, i.e., pulse and surge. It is well established that both modes of LH secretion correspond to the pulse and surge modes of gonadotropin-releasing hormone releases in the hypothalamus, as was reported in sheep [4, 9]. Of these modes of LH secretion, an analysis of LH pulses requires frequent blood sampling at intervals of no more than 10 min in small rodents [10]. In addition, blood samples should be collected under stress-free conditions, since LH secretion is known to be strongly affected by various types of stresses, such as physical [10], psychological [11] or nutritional stresses [12]. Frequent blood sampling techniques, therefore, have been established in various mammals to detect pulsatile LH secretions in conscious freemoving animals under stress-free conditions.

Mice have become more important as a genetically-modified model animal in the analysis of physiological functions. The analysis of pulsatile LH secretion using frequent blood sampling, however, is considered problematic in mice because their blood volume and composition might be adversely affected by such frequent sampling for their small body size. Attempts have been made to obtain frequent blood samples using several techniques, such as

Received: June 1, 2011

Accepted: June 18, 2011

Published online in J-STAGE: July 30, 2011

(C)2011 by the Society for Reproduction and Development

Correspondence: K Maeda (e-mail: kei_maeda@nagoya-u.jp) orbital sinus puncture and tail cutting. These procedures should not be used for the analysis of LH pulses because they might be so stressful that the pulses would be seriously affected. There are a few reports showing LH pulses with frequent blood sampling [1316], but the pulse profiles were not as good as those of other animal species.

The present study aims to establish a blood sampling technique that would reveal the pulsatile and surge nature of LH secretion in female mice. To this end, blood samples were taken every $3 \mathrm{~min}$ for $1.5 \mathrm{~h}$ in conscious free-moving female mice to detect pulsatile LH secretion. The surge mode of $\mathrm{LH}$ secretion was also examined at 1-h intervals between 1300 and $2200 \mathrm{~h}$.

The mice undergoing frequent blood sampling in the present study might be largely free from stress, since their blood glucose levels, an indicator of the stress, were constantly maintained at a normal level throughout the sampling in ad-lib fed mice (Fig. 1). Furthermore, the blood glucose levels were also kept constant in fasted animals at a significantly lower level compared with $a d-l i b$ fed animals. This implies that the current sampling protocol should prove useful in detecting physiological changes of circulating metabolites. Another issue concerns the decrease in red blood cells, which may have a serious impact on the animals because the blood volume collected during a 1.5 -h sampling period was $30 \%$ of their estimated total blood volume. In the present study, no change in body weight or hematocrit values was detected during the blood sampling (data not shown). Thus, it is most likely that the sampling protocol employed in the present study overcame the technical difficulties predicted in mice.

Obvious LH pulses were observed in ad lib-fed ovariectomized mice (Fig. 2A). The mean frequency of LH pulses was $4.64 \pm 0.65$ 


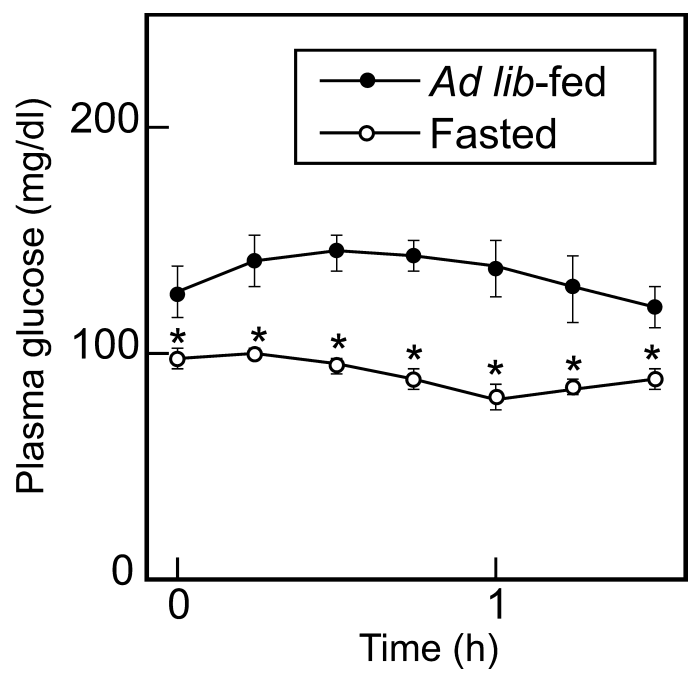

Fig. 1. Changes in mean plasma glucose levels in ad lib-fed and 24-h fasted ovariectomized mice. Values are means \pm SEM (ad libfed, $\mathrm{n}=4 ; 24$-h-fasted, $\mathrm{n}=6$ ). $* \mathrm{P}<0.05$, vs. ad lib-fed controls (Bonferroni test).

pulses/1.5 h (mean \pm SEM; Fig. 2B), while the mean LH pulse interval was $19.99 \pm 1.99$ min (mean \pm SEM). The interval seemed much shorter than in other animal species undergoing ovariectomy, such as rats (32 $\mathrm{min})$ [17], rhesus monkeys (50 $\mathrm{min})$ [7], goat (25 min) [18], ewes (62 $\mathrm{min}$ ) [19], gilts (79 $\mathrm{min}$ ) [20] and beef heifers (127 $\mathrm{min}$ ) [21]. Figure 3 shows that the size of the animal species bears a positive relationship to its LH pulse intervals.

Other groups of mice were also bled every $3 \mathrm{~min}$ for $1.5 \mathrm{~h}$ after 24-h fasting to discover whether the present sampling protocol was capable of detecting suppressed LH pulses, as has been reported in other animal species such as rats $[12,22]$. Food deprivation has been known to suppress the pulsatile LH release in various mammalian species via a specific neural pathway [23], indicating that food deprivation might be useful as an environmental cue to modulating reproductive functions. The mean $\mathrm{LH}$ levels and frequency of LH pulses decreased significantly $(\mathrm{P}<0.05)$ after 24 -h fasting in ovariectomized mice (Fig. 2B). Thus, the present study clearly demonstrated that the current sampling protocol was suitable for detecting physiological changes in pulsatile LH secretion in mice. It has been reported that 48-h fasting suppresses LH pulses only in the presence of estrogen in rats [17], whereas prolonged fasting for $120 \mathrm{~h}$ suppresses LH secretion in the absence of estrogen [24], suggesting that severe nutritional stress affects gonadal functions without the aid of estrogen. The present study suggests that 24-h fasting in mice is severe enough to suppress LH pulses in the absence of estrogen.

The surge mode of LH secretion is usually analyzed by a singlepoint blood sampling protocol in mice, which might miss the peak of a surge in each individual mouse. In the present study, LH surges were clearly detected using the serial blood-sampling protocol. Indeed, Fig. 4 shows considerable individual variations in the timing of surge peaks. We demonstrated in this study that the
A

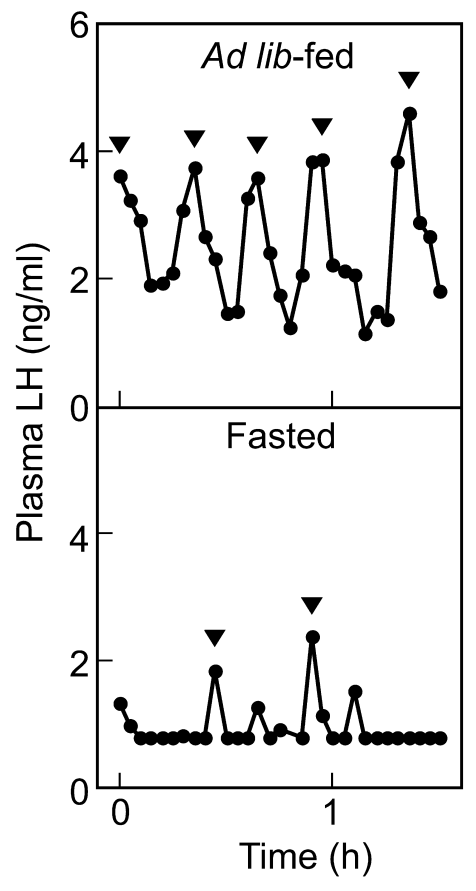

$B$

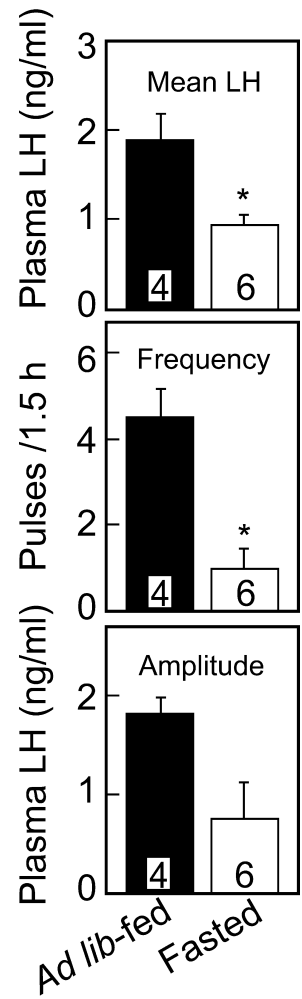

Fig. 2. A: Representative plasma LH profiles in ad lib-fed or 24-hfasted ovariectomized mice. Blood samples were collected for $1.5 \mathrm{~h}$ at 3 -min intervals. Arrowheads indicate peaks of $\mathrm{LH}$ pulses identified by the PULSAR computer program. B: Mean plasma LH concentrations and the frequency and amplitude of LH pulses in ad lib-fed or 24-h-fasted ovariectomized mice. Values are means \pm SEM. Numbers in each column represent the number of animals used. ${ }^{*} \mathrm{P}<0.05, v s$. the $a d$ lib-fed group.

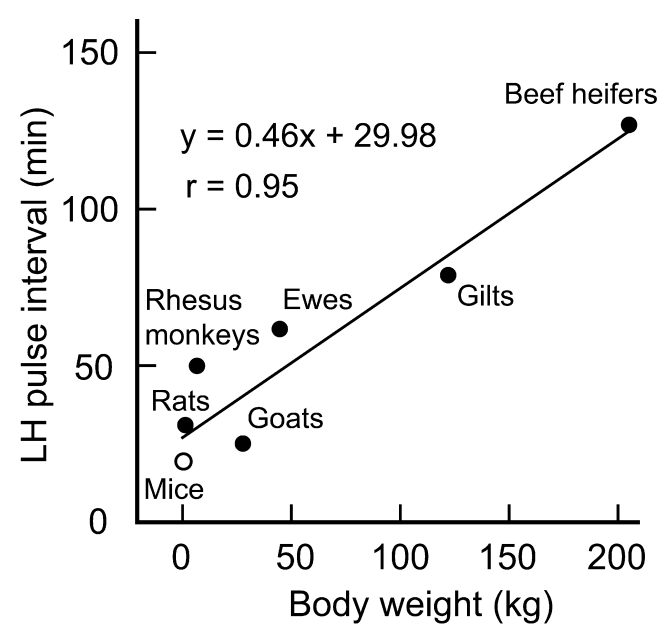

Fig. 3. Correlation between body weight and LH pulse interval in mice (open circle) and other animal species (solid circles), such as rats [17], rhesus monkeys [7], goats [18], ewes [19], gilts [20] and beef heifers [21]. 


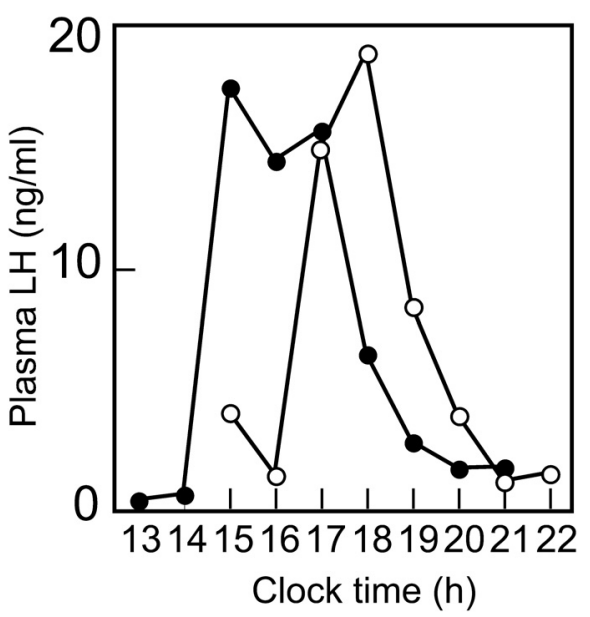

Fig. 4. Individual profiles of preovulatory LH surges in two proestrous mice. Blood samples $(20 \mu \mathrm{l})$ were collected at 1-h intervals between 1300 and $2200 \mathrm{~h}$.

present blood sampling protocol allows us to collect serial blood samples during an LH surge, thus providing more information from each individual mouse.

In the present study, a 22-cm cannula was employed to minimize the dead volume at each blood collection, since a long atrial cannula may cause dilution of the collected blood with the saline. The blood glucose concentrations determined in the present study were very similar to those of blood samples collected following decapitation [25-27], suggesting that the present blood samples might not have been diluted with the saline in the cannula.

In conclusion, the present study developed a frequent blood sampling protocol for analysis of pulse and surge modes of $\mathrm{LH}$ secretion in freely-moving conscious mice. Such findings will contribute to studies on the mechanisms regulating reproductive functions by assessing LH secretion in transgenic and knockout mice. In addition, the present blood sampling protocol may be suitable for analysis of not only LH but also of other hormones and metabolic substances in the circulation of genetically-modified mice.

\section{Methods}

\section{Animals}

Thirteen to fifteen-week-old female ICR strain mice (Charles River Laboratories Japan, Kanagawa, Japan) weighing 29-36 g were housed in a controlled environment ( $14 \mathrm{~h}$ light: $10 \mathrm{~h}$ darkness with lights-on at $0500 \mathrm{~h}, 23 \pm 3 \mathrm{C}$ ) and had free access to food (CE2, CLEA Japan, Tokyo, Japan) and water. Surgeries were performed under isoflurane anesthesia and aseptic conditions. The present study was approved by the Committee on Animal Experiments of the Graduate School of Bioagricultural Sciences, Nagoya University.
A

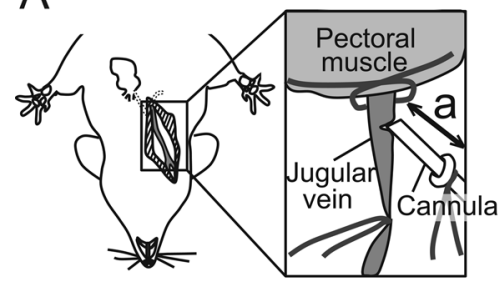

B
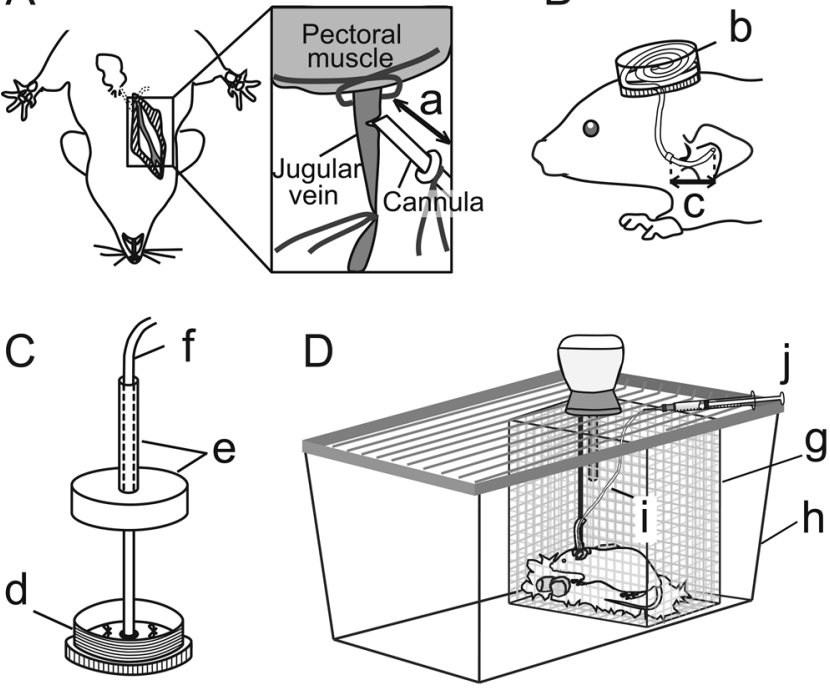

Fig. 5. Schematic illustrations of the equipment and methods for intraatrial cannula during frequent blood sampling from freelymoving conscious mice. A: Cannula with a stopper affixed 1.4 $\mathrm{cm}$ from the tip. B: Plastic cannula case attached to the neck with a cannula inside (B-b). The length between the tip of the cannula and incision of the jugular vein is $1.4 \mathrm{~cm}(\mathrm{~B}-\mathrm{c}) . \mathrm{C}$ : Plastic cannula case body for blood sampling affixed to the neck $(\mathrm{C}-\mathrm{d})$. The top with a sheath $(\mathrm{C}-\mathrm{e})$ protects the cannula $(\mathrm{C}-\mathrm{f})$ from mouse bites. D: Stainless-steel sampling cage (D-g, $100 \times 150 \times 150-\mathrm{mm})$ inside the plastic cage $(\mathrm{D}-\mathrm{h}, 230 \times 320 \times$ 170-mm). Silicon cannula connected to a $1-\mathrm{ml}$ syringe on the cage (D-i,j).

\section{Surgeries}

Mice were bilaterally ovariectomized for a week before blood sampling to obtain obvious LH pulses without the negative feedback effect of steroid hormones. The animals then received an indwelling atrial cannula made of silicon tubing (i.d., $0.5 \mathrm{~mm}$; o.d., $1.0 \mathrm{~mm}$; length, $22 \mathrm{~cm}$, Shin-Etsu Polymer, Tokyo, Japan) through the right jugular vein 2 days before blood sampling. The cannula was inserted through a small incision made in the jugular vein using microscissors and was affixed to the pectoral muscle (Fig. 5A). The cannula was similar to the one reported in rats [28], except that the total length was $22 \mathrm{~cm}$, and the distance between the tip of the cannula and the incision of the jugular vein was $1.4 \mathrm{~cm}$ to prevent the cannula from being bent (Fig. 5A-a). The cannula was kept in a plastic case (Fig. 5B-b, $28 \mathrm{~mm}$ in diameter, Piston-Can B1, M.I. Chemical, Hyogo, Japan) affixed to the dorsal skin of the neck until blood sampling (Fig. 5B). Food intake recovered to normal levels in all the $a d$ lib-fed mice within 2 days after surgery, suggesting that the animals had recovered from surgery by the day of blood sampling. To detect proestrous LH surges, those exhibiting at least two consecutive 5-day estrous cycles received the indwelling atrial cannula on the day of diestrus 1. Some animals showed irregular estrous cycle after surgeries, and samples were not collected in these individuals. 


\section{Blood sampling}

The cover of the plastic case was substituted for one with a sheath made of straw tubing to prevent cannula damage from mice bites (Fig. 5C). Mice were kept in a wire meshed sampling box placed inside a plastic cage (Fig. 5D). The cannula was connected to a $1-\mathrm{ml}$ syringe containing heparinized saline kept at the top of the cage. Blood samples $(20 \mu \mathrm{l})$ were collected through the intraatrial cannula at 3-min intervals for $1.5 \mathrm{~h}$ from $1300 \mathrm{~h}$ to determine LH pulses. An additional volume $(10 \mu \mathrm{l})$ of blood samples was obtained at 15-min intervals to detect the blood glucose levels during blood sampling. To determine LH surges, blood samples (20 $\mu \mathrm{l})$ were collected in proestrous animals at $1-\mathrm{h}$ intervals between 1300 and 2200 h. Figure 4 shows LH surges in 2 proestrous animals. Each blood sample was replaced with an equivalent volume of washed red blood cells obtained from other ICR strain mice to keep the hematocrit values constant. To prevent the loss of blood samples, the syringes were put in plastic tubes and then centrifuged at 3,000 rpm. The samples were then stored at $-20 \mathrm{C}$ until assayed. Before and after blood sampling, body weights were measured and blood samples $(20 \mu \mathrm{l})$ were collected to determine hematocrit values.

\section{Assays}

Plasma LH concentrations were determined with a mouse LH RIA kit provided by the National Hormone and Peptide Program (Bethesda, MD, USA). LH concentrations were expressed in terms of NIDDK mouse LH-RP AFP-5306A. The least detectable concentration of LH in $10-\mu$ l plasma samples was $0.78 \mathrm{ng} / \mathrm{ml}$. The intra- and interassay coefficients of variation were 7.8 and $11.0 \%$ at 4.8 and $3.0 \mathrm{ng} / \mathrm{ml}$, respectively.

Plasma glucose concentrations were determined by the glucose oxidase method using a commercial kit (Glucose C-Test, Wako, Osaka, Japan). The least detectable concentration of glucose in 1.5 - $\mu$ l plasma sample was $50.0 \mathrm{mg} / \mathrm{dl}$, and the intra-assay coefficient of variation was $1.6 \%$ at $131.1 \mathrm{mg} / \mathrm{dl}$.

\section{Data analysis}

LH pulses were identified using the PULSAR computer program [29]. The criteria used to identify the pulses were chosen so that a single LH concentration had to be 3.0 standard deviation (SD) greater than the baseline LH concentration, 2 consecutive LH concentrations each had to be $1.0 \mathrm{SD}$ greater or 3 or more consecutive LH concentrations each had to be 0.4 SD greater than the baseline $\mathrm{LH}$ concentration to be considered part of an LH pulse. The SD for each plasma concentration was calculated by the equation $\mathrm{y}=(2.78 \mathrm{x}$ $+23.62) / 100$, where $x$ is the LH level and $y$ is the SD for each LH level determined by assaying four series of control plasma in 10 replicates. The mean $\mathrm{LH}$ concentration and frequency and amplitude of LH pulses were compared between treatments using the Student's $t$-test. Statistical differences in plasma glucose levels between groups were analyzed by two-way ANOVA (with treatment and time as main effects) followed by the Bonferroni test.

\section{Acknowledgments}

We thank the National Hormone and Peptide Program (NHPP),
National Institute of Diabetes and Digestive and Kidney Diseases (NIDDK), and are indebted to Dr AF Parlow for providing the LH assay kit and to Drs GR Merriam and KW Wachter for the PULSAR computer program. The LH pulse analyses and radioimmunoassays were performed at the Nagoya University Information Technology Center and Nagoya University Radioisotope Center, respectively. This work was supported in part by the Program for Promotion of Basic Research Activities for Innovative Biosciences (PROBRAIN) of Japan and Grants-in-Aid (Nos. 23380163 and 23580402) from the Japanese Ministry of Education, Culture, Sports, Science and Technology.

\section{References}

1. Maeda K, Tsukamura H, Ohkura S, Kawakami S, Nagabukuro H, Yokoyama A. The LHRH pulse generator: a mediobasal hypothalamic location. Neurosci Biobehav Rev 1995; 19: 427-437.

2. Gore AC, Terasawa E. Neural circuits regulating pulsatile luteinizing hormone release in the female guinea-pig: opioid, adrenergic and serotonergic interactions. $J$ Neuroendocrinol 2001; 13: 239-248.

3. Noguchi M, Yoshioka K, Kaneko H, Iwamura S, Takahashi T, Suzuki C, Arai S, Wada Y, Itoh S. Measurement of porcine luteinizing hormone concentration in blood by time-resolved fluoroimmunoassay. J Vet Med Sci 2007; 69: 1291-1294.

4. Moenter SM, Brand RM, Midgley AR, Karsch FJ. Dynamics of gonadotropin-releasing hormone release during a pulse. Endocrinology 1992; 130: 503-510.

5. Tanaka T, Ozawa T, Hoshino K, Mori Y. Changes in the gonadotropin-releasing hormone pulse generator activity during the estrous cycle in the goat. Neuroendocrinology 1995; 62: 553-561.

6. Rahe CH, Owens RE, Fleeger JL, Newton HJ, Harms PG. Pattern of plasma luteinizing hormone in the cyclic cow: dependence upon the period of the cycle. Endocrinology 1980; 107: 498-503.

7. Vulliemoz NR, Xiao E, Xia-Zhang L, Germond M, Rivier J, Ferin M. Decrease in luteinizing hormone pulse frequency during a five-hour peripheral ghrelin infusion in the ovariectomized rhesus monkey. J Clin Endocrinol Metab 2004; 89: 5718-5723.

8. Fitzgerald BP, I'Anson H, Loy RG, Legan SJ. Evidence that changes in LH pulse frequency may regulate the seasonal modulation of LH secretion in ovariectomized mares. J Reprod Fertil 1983; 69: 685-692.

9. Moenter SM, Brand RC, Karsch FJ. Dynamics of gonadotropin-releasing hormone $(\mathrm{GnRH})$ secretion during the GnRH surge: insights into the mechanism of GnRH surge induction. Endocrinology 1992; 130: 2978-2984.

10. Rivier C, Rivier J, Vale W. Stress-induced inhibition of reproductive functions: role of endogenous corticotropin-releasing factor. Science 1986; 231: 607-609.

11. Lin Y, Li X, Lupi M, Kinsey-Jones JS, Shao B, Lightman SL, O'Byrne KT. The role of the medial and central amygdala in stress-induced suppression of pulsatile LH secretion in female rats. Endocrinology 2011; 152: 545-555.

12. Cagampang FR, Maeda K, Yokoyama A, Ota K. Effect of food deprivation on the pulsatile LH release in the cycling and ovariectomized female rat. Horm Metab Res 1990; 22: 269-272.

13. Coquelin A. Absence of female-induced luteinizing hormone release in orchidectomized, sexually active mice. Biol Reprod 1991; 45: 424-431.

14. Gibson MJ, Miller GM, Silverman AJ. Pulsatile luteinizing hormone secretion in normal female mice and in hypogonadal female mice with preoptic area implants. Endocrinology 1991; 128: 965-971.

15. Kokoris GJ, Lam NY, Ferin M, Silverman AJ, Gibson MJ. Transplanted gonadotropin-releasing hormone neurons promote pulsatile luteinizing hormone secretion in congenitally hypogonadal (hpg) male mice. Neuroendocrinology 1988; 48: 45-52.

16. Suter KJ, $\mathbf{O}^{\prime}$ Farrell L. Impaired episodic LH secretion in female mice with GFP in GnRH neurons. Am J Physiol Endocrinol Metab 2008; 295: E130-136.

17. Cagampang FR, Maeda KI, Tsukamura H, Ohkura S, Ota K. Involvement of ovarian steroids and endogenous opioids in the fasting-induced suppression of pulsatile $\mathrm{LH}$ release in ovariectomized rats. J Endocrinol 1991; 129: 321-328.

18. Wakabayashi Y, Nakada T, Murata K, Ohkura S, Mogi K, Navarro VM, Clifton DK, Mori Y, Tsukamura H, Maeda K, Steiner RA, Okamura H. Neurokinin B and dynorphin A in kisspeptin neurons of the arcuate nucleus participate in generation of periodic oscillation of neural activity driving pulsatile gonadotropin-releasing hormone secretion in the goat. J Neurosci 2010; 30: 3124-3132.

19. Molter-Gerard C, Fontaine J, Guerin S, Taragnat C. Differential regulation of the gonadotropin storage pattern by gonadotropin-releasing hormone pulse frequency in 
the ewe. Biol Reprod 1999; 60: 1224-1230.

20. Estienne MJ, Hurlock WF, Barb CR. Serum concentrations of luteinizing hormone, growth hormone, and cortisol in gilts treated with $\mathrm{N}$-methyl-D,L-aspartate during the estrous cycle or after ovariectomy. J Anim Sci 1998; 76: 2162-2168.

21. Kiser TE, Kraeling RR, Rampacek GB, Landmeier BJ, Caudle AB, Chapman JD. Luteinizing hormone secretion before and after ovariectomy in prepubertal and pubertal beef heifers. J Anim Sci 1981; 53: 1545-1550.

22. Bronson FH. Effect of food manipulation on the GnRH-LH-estradiol axis of young female rats. Am J Physiol 1988; 254: R616-621.

23. Tsukamura $\mathbf{H}$, Maeda $\mathbf{K}$. Non-metabolic and metabolic factors causing lactational anestrus: rat models uncovering the neuroendocrine mechanism underlying the suckling-induced changes in the mother. Prog Brain Res 2001; 133: 187-205.

24. Dyer RG, Mansfield S, Corbet H, Dean AD. Fasting impairs LH secretion in female rats by activating an inhibitory opioid pathway. J Endocrinol 1985; 105: 91-97.
25. Bland ML, Jamieson CA, Akana SF, Bornstein SR, Eisenhofer G, Dallman MF, Ingraham HA. Haploinsufficiency of steroidogenic factor-1 in mice disrupts adrenal development leading to an impaired stress response. Proc Natl Acad Sci USA 2000; 97 14488-14493.

26. Erenmemisoglu A, Ozdogan UK, Saraymen R, Tutus A. Effect of some antidepressants on glycaemia and insulin levels of normoglycaemic and alloxan-induced hyperglycaemic mice. J Pharm Pharmacol 1999; 51: 741-743.

27. Negishi M, Shimizu H, Ohtani K, Mori M. Acarbose partially prevents the development of diabetes mellitus by multiple low-dose streptozotocin administration. Diabetes Res Clin Pract 1996; 33: 15-19.

28. Tsukamura $\mathbf{H}$, Maeda $\mathbf{K}$. A frequent blood sampling protocol in freely-moving unanesthetized rats. Comparative Endocrinology 1997; 86: 17-22 (In Japanese).

29. Merriam GR, Wachter KW. Algorithms for the study of episodic hormone secretion. Am J Physiol 1982; 243: E310-318. 